\title{
The role of Neurotensin and its receptors in non-gastrointestinal cancers: a review
}

\author{
Stella Nikolaou ${ }^{1,2,3}$, Shengyang Qiu ${ }^{1,3}$, Francesca Fiorentino ${ }^{3}$, Constantinos Simillis ${ }^{1}$, Shahnawaz Rasheed ${ }^{1,2,3}$, \\ Paris Tekkis ${ }^{1,2,3}$ and Christos Kontovounisios ${ }^{1,2,3^{*}}$
}

\begin{abstract}
Background: Neurotensin, originally isolated in 1973 has both endocrine and neuromodulator activity and acts through its three main receptors. Their role in promoting tumour cell proliferation, migration, DNA synthesis has been studied in a wide range of cancers. Expression of Neurotensin and its receptors has also been correlated to prognosis and prediction to treatment.

Main body: The effects of NT are mediated through mitogen-activated protein kinases, epidermal growth factor receptors and phosphatidylinositol-3 kinases amongst others. This review is a comprehensive summary of the molecular pathways by which Neurotensin and its receptors act in cancer cells.

Conclusion: Identifying the role of Neurotensin in the underlying molecular mechanisms in various cancers can give way to developing new agnostic drugs and personalizing treatment according to the genomic structure of various cancers.
\end{abstract}

Keywords: Neurotensin, Neurotensin receptors, Cancer

\section{Background}

Neurotensin (NT) was first detected by Carraway and Leeman in bovine hypothalamus in 1973 [1]. It is a 13-amino acid regulatory peptide present in both the central nervous system (hypothalamus and pituitary) and the gastrointestinal tract (N cells of the jejunum and ileum) [1, 2]. NT is produced from pre-pro-neurotensin, which contains the NT1-13 and neuromedin N [3]. It is released as a response to luminal fat contents and its physiological functions include increasing intestinal motility [4], increasing pancreatic and biliary secretions $[2,5]$ and stimulating the growth of various tissues like the gut, pancreas, adrenal gland and liver [2]. In the CNS, it is thought to inhibit dopaminergic pathways [2] and have opioid-independent analgesic properties. NT acts through 3 main receptors:

\footnotetext{
* Correspondence: c.kontovounisios@imperial.ac.uk

'Department of Colorectal Surgery, Chelsea and Westminster Hospital, NHS Foundation Trust, London, UK

${ }^{2}$ Department of Colorectal Surgery, Royal Marsden Hospital, London, UK

Full list of author information is available at the end of the article
}

Neurotensin receptor 1(NTSR1), NTSR2 and NTSR3 (or sortilin 1) [6]. The first two are seven-transmembrane Gprotein coupled receptors and the latter is a single transmembrane domain sorting receptor [6].

The NT gene transcription is transiently expressed in fetal tissues of organs like the liver, pancreas and colon and yet is suppressed in adult tissue [7]. NT's role in cancer is believed to stem from modifications in the NT gene regulation involving Ras dysregulation and changes to methylation patterns of cytosine-phosphorus-guanine (CpG) sites in the NT promoter region [6].

Among the receptors' involvement in cancer, NTSR1 is the most studied [8]. NTSR1 is comprised of 424 amino acids and has a high affinity for NT [8]. The NT/ NTSR1 complex leads to phospholipase C (PLC) activation with subsequent production of inositol triphosphate (IP3) and diacylglycerol (DAG) from membrane phospholipids [8]. Protein Kinase C (PKC) activation and intracellular calcium mobilization lead to cell proliferation, survival, migration and invasion [8]. 
NTSR2 is a low affinity, 410-amino acid receptor which is $64 \%$ homologous to NTSR1 [8]. NTSR2 expression has been reported in prostate cancer, glioma and chronic lymphocytic leukaemia (CLL) [6]. The exact signaling pathway involved in the role of NTSR2 is celldependent and currently, there is little information in its underlying mechanism of action $[6,8]$.

NTSR3 (sortilin 1) receptor, contrary to the other 2 receptors, is a single transmembrane domain receptor and is not specific to NT [6]. Other ligands for this receptor include lipoprotein lipase, receptor associated protein (RAP), pro-neurotrophins and sphingolipid activator protein (SAP) [6]. NTSR3's role in cancer is largely mediated by soluble NTSR3 (sNTSR3), which is released by shedding the extracellular domain of NTSR3 [6]. sNTSR3 increases calcium concentration and induces focal adhesion kinase (FAK)/Src-dependent activation of inositol 1,4,5-triphosphate (IP3) kinase pathway, regulates cell morphology and impairs cell cohesion in colorectal cancer cell lines [6]. Sortilin has also been implicated in the tyrosine kinase and epidermal growth factor complex, exerting control on endothelial cells and angiogenesis [9].

Our team has already published a review summarizing the signaling pathway of NT in colorectal cancer and the clinical implications [10]. This review aims to explore the role of NT and its receptors in non-gastrointestinal cancers.

\section{Lung cancer}

In the United Kingdom (UK), lung cancer is the third commonest cancer and the commonest cause of cancer death. There are two main types of lung cancer: small cell lung cancer (SCLC) and non-small cell lung cancer (NSCLC). The latter can be further subdivided into large cell lung carcinoma, squamous cell carcinoma and adenocarcinoma [11]. In the western world, the adenocarcinoma subtype of NSCLC is the commonest [11]. The 5-year survival for lung cancer is still low (10 to $20 \%$ ) and the stage of the disease determines the prognosis [12]. Interestingly, within a stage, survival differs. Therefore, determining the underlying molecular pathways which drive these differences, is important. Drugs targeting epidermal growth factor receptors and their downstream signaling effectors have shown therapeutic efficacy, but eventually, there is disease progression resulting in death [13].

NT has been postulated to be one of the regulatory peptides in both SCLC $[14,15]$ and NSCLC $[16,17]$ in in-vitro studies. The postulated mechanism is that NT and NTSR1 interaction causes EGFR, HER2, and HER3 over-expression and activation of lung tumour cells [12]. In one study, blocking the NTSR1 receptor with SR48692 in human NSCLC cells, resulted in a potentiated effect of gefitinib, a tyrosine kinase inhibitor already in clinical use, in inhibiting the growth of NCIH1299 and A549 cells [16].

NTSR1 present in the cytoplasm, as in lung adenocarcinoma is correlated with a poor prognosis, however, if it is located on the cell surface, as in lung squamous cell carcinoma, then NTSR1 has no bearing on prognosis [12]. In a clinical series of 138 stage I primary NSCLC adenocarcinomas treated only with surgery, NT was expressed in $60.4 \%$ of the cases, NTSR 1 was expressed in $59.7 \%$ and both, NT and NTSR1, were expressed in $38.8 \%$ of the cases [11]. In the same study, univariate analysis showed that NTSR1 expression was associated with a worse 5-year survival rate $(p=0.0081)$ and relapse-free survival $(p=0.0024)$ [11]. In multivariate analysis, age greater than 65 years old $(p=0.0018)$ and NTSR1 expression $(p=0.0034)$, were independent negative prognostic indicators [11]. The same research group showed that high expression of NTSR1 was an independent negative prognostic marker in 389 patients with lung adenocarcinoma, stages I to III [12]. NTSR1 overexpression has also been correlated to worse sensitivity to platinum-based chemotherapy in patients with NSCLC [18]. Currently, standard chemotherapy agents include platinum-salt compound with an antimetabolite or a spindle poison [18]. Although this regime increases overall survival (OS) up to 12 months or more, patients still develop progressive disease and die [18]. Targeted therapies are now recommended in 15 to $20 \%$ of NSCLC patients who have specific mutations (e.g. in EGFR) [18]. Although these have less toxicity, most of the patients eventually develop resistance and progressive disease [18]. Resistance develops due to tumour cell plasticity and manipulation of this can improve the performance of anti-tumour drugs [18]. Wu Z et al., firstly, showed that NTSR1 over-expression is correlated with worse sensitivity to platinum-based chemotherapy agents and more tumour aggressiveness [18]. They also studied NTSR2 expression in 28 advanced stage non-squamous NSLC; staining was mainly in the cytoplasm (i.e. different to the NTSR1 distribution) and did not correlate to OS [18]. A monoclonal antibody against the longfragment NT (LF-NT) in xenografted lung cancer cells, showed a neutralizing effect on cell growth and migration by $20-30 \%$, as well as reduced metastasis. It also restored the cisplatin response in a dose-dependent manner without significant side effects [18].

NTSR3 or sortilin 1 has been implicated in the loading of EGFR into exosomes and sortilin depletion maintains EGFR on the cell surface, limiting EGFR endocytosis [19]. NTSR3 normally cycles between the cell membrane and the trans-Gogi network. NTSR3 binds both stimulated and unstimulated EGFR, leading to its internalization. This eventually leads to EGFR expulsion via 
exosomes or in receptor degradation and hence signal termination [19]. Al-Akhrass et al. found that low sortilin expression was associated with increased cellular proliferation and tumour growth, indicating that NTSR3 is a favorable prognostic marker in lung adenocarcinoma patients [19]. His team also performed immunohistochemical analysis on 78 patients with NSCLCs (grades IIII; well to poorly differentiated); sortilin expression decreased significantly with pathologic grade and was associated with poorer prognosis [19].

Currently, only EGFR-mutated tumors are eligible to receive EGFR tyrosine kinase inhibitors, which represent only $10 \%$ of all lung adenocarcinomas. Preclinical trials of erlotinib showed good response in xenografted models harbouring NT/NTSR1 but no effect if NT/NTSR1 were absent. A phase II clinical trial of Afatinib (a selective irreversible erbB family blocker) used as a third- or further-line treatment in patients with stage IV bronchial adenocarcinoma which harbor wildtype EGFR and express the Neurotensin-neurotensin receptor complex (THEN), has been withdrawn due to 'medical reasons' which are not further explained.

\section{Pancreatic cancer}

Pancreatic cancer is an extremely aggressive cancer with poor prognosis and this is due to the late stage of diagnosis [20]. NT has been found to increase pancreatic secretions among other physiological functions [20]. NT and its receptors play a role in the pathological growth of cancer cells, including human pancreatic cancer cells, as shown in in-vitro studies [20,21]. Addition of NT to pancreatic cell lines stimulates DNA synthesis via protein kinase (ERK-1 and ERK-2) activation [22-25]. The combination of NT and epidermal growth factor (EGF) in PANC-1 and Mia PACA-2 cells result in a prolonged duration of ERK pathway activation leading to DNA synthesis [24]. Both NT and EGF induce extracellular acidification and intracellular alkalinization through the $\mathrm{Na}$ / $\mathrm{H}^{+}$exchanger 1(NHE1) leading to interleukin-8 (IL-8) synthesis and promoting glycolysis leading to increased tumor cell invasion [26]. Furthermore, NT/NTSR3 complex modifies the expression of $\alpha \mathrm{V}$ and $\beta 5$ integrin subunits in PDACs cultured on vitronectin. This results in a reduced level of migration of collectively migrating

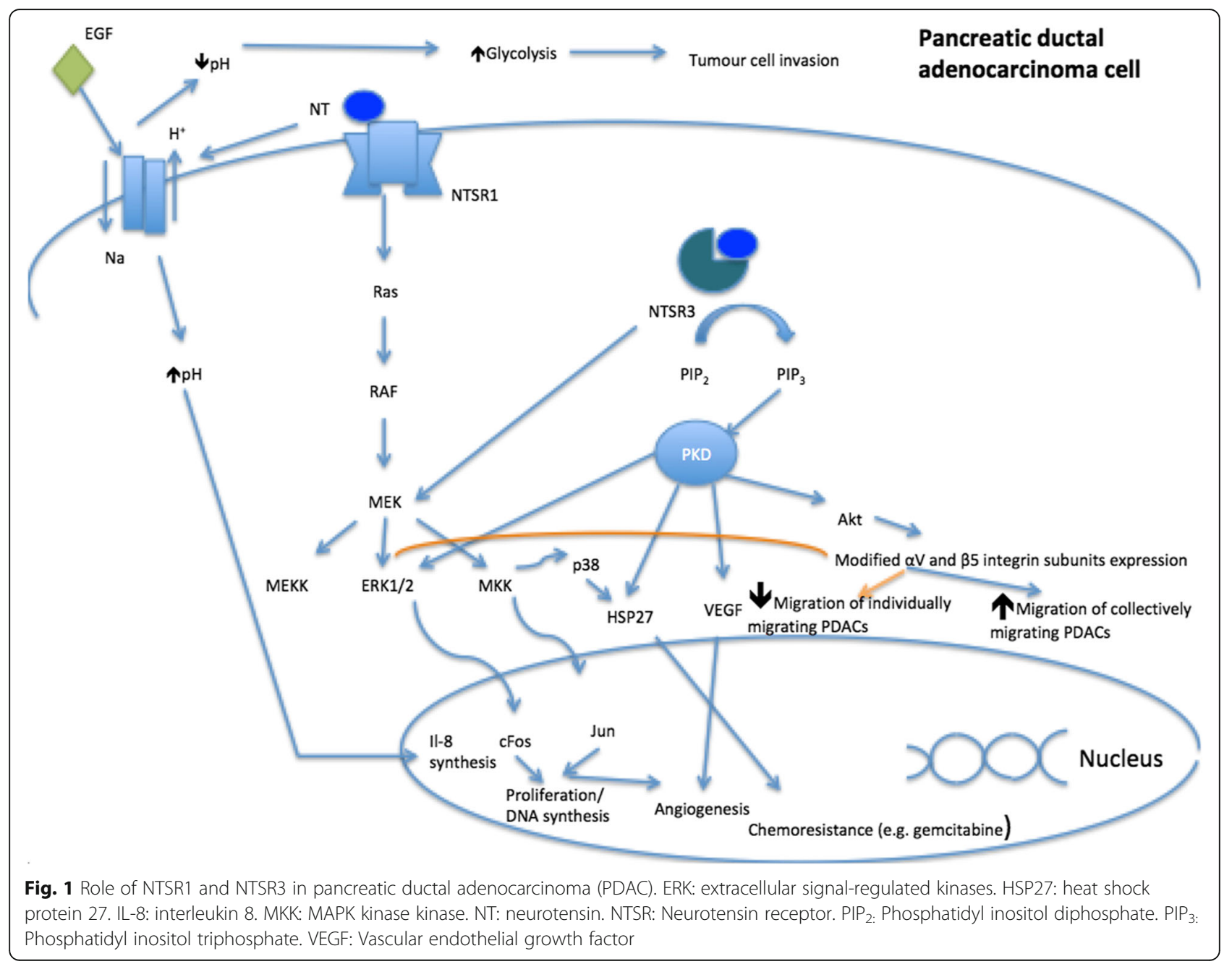


PDACs via the PI3 kinase pathway, whilst increases the migration potential of individually migrating PDACs via the EGFR/ERK pathway [27]. Figure 1 summarises the potential pathways in carcinogenesis of NT in pancreatic cancer cells.

Pancreatic ductal adenocarcinoma overexpresses NTSR1 and NT, whilst normal pancreatic tissue does not $[28,29]$. The intensity of NTSR1 increases with the stage of pancreatic cancer and metastases express NTSR1 at the same level as the primary tumour [30]. Preliminary studies showed that NTSR1 is a promising target for therapeutic and diagnostic purposes [31, 32]. Baum and colleagues tested the use of radiopharmaceutical therapy, using an NTSR1 antagonist, in 6 patients with advanced pancreatic adenocarcinoma [30]. They used ${ }^{177} \mathrm{Lu}-3 \mathrm{BP}-227$ as an intravenous agent to assess uptake and then one of the patients proceeded to have 3 further intraperitoneal doses. Tumor uptake was observed in 5 out of 6 patients and one of the patients achieved a partial remission with improved quality of life and 11-month survival despite a very poor prognosis [30]. There is currently an ongoing phase I and II trial, in evaluating ${ }^{177} \mathrm{Lu}-3 \mathrm{BP}-227$ 's safety and efficacy in various cancers including pancreatic cancer [33].

\section{Breast cancer}

Breast cancer is one of the commonest causes of cancer deaths in the western world and despite improvements in early detection, surgery and targeted therapy, one in four women still die from this disease [34]. This is mainly due to the development of metastatic disease and it is therefore important to identify new markers of progression and develop highly specific treatments targeted to metastasis to improve survival [34].

NT and NTSR1 have been implicated in breast cancer progression $[8,35]$ and high levels of pro NT in the blood is linked to a higher risk of breast cancer [36]. The NT/NTSR1 complex enhances tumour growth and metastasis [37].

A study by Souaze et al. showed that $34 \%$ of invasive ductal breast carcinoma (IDC) specimens express NT, 91\% express NTSR1 and 30\% express both NT and NTSR1 [38]. The same team also showed that NTSR1 was involved in cellular migration, invasion and induction of matrix metalloproteases-9 (MMP-9) and use of SR48692 (an NTSR1 antagonist) halted tumor growth in triple-negative cancer cells (MDA-MB-231) xenografted in nude mice [38]. Subsequent studies in triple-negative breast cancer phenotype cells (MDA-MB-231) which were xenografted in nude female mice, and were treated with both intravenous and intratumoral NT polyplex nanoparticles harboring the herpes simplex virus thymidine kinase suicide gene and ganciclovir, showed a significant growth inhibition $(55-60 \%)(p<0.001)$ [39].
High NTSR1 in patients with IDCs is correlated with larger tumor size, Scarff-Bloom-Richardson (SBR) histoprognostic grade 3 and number of positive lymph nodes. These patients also have worse survival compared to those with low NTSR1 expression (10-year survival rate of $66.2 \%$ versus $96.5 \%, p=0.01$ ) [34].

The NT/NTSR1 complex enhances tumour aggressiveness by increasing human epidermal growth factor receptor (HER) expression and activation via the release of specific EGFR, HER2 and HER3 ligands [37]. Use of lapatinib, an EGFR/HER2 tyrosine kinase inhibitor, and metformin reduced the growth of cells overexpressing NT/NTSR1 in an experimental mouse model, suggesting that NT/NTSR1 as a potential therapeutic target [37].

\section{Prostate cancer}

Androgen treatment provides a temporary therapeutic response in prostate cancer, as eventually, a more aggressive and androgen-independent tumour tends to develop after initial therapy [40]. Discovery of molecular targets is therefore important in treating advanced prostate cancer.

The NT receptor pathway has been particularly implicated as an alternative growth pathway, especially in the absence of androgens [41, 42]. NT, binding to NTSR1, causes prostatic cancer cell mitosis through Src-, MMPand PKC-dependent transactivation of EGFR, which ultimately stimulate the MAP-kinase pathway in a PI3Kdependent manner [43-45]. NT and its receptors have been implicated in the neuroendocrine differentiation of prostate cancers [46]. Moreover, NTSR1 blockade with the selective NTSR1 antagonist, SR48692, inhibits Neurotensin-mediated prostatic cancer growth [44, 47].

Patients treated with long-term anti-androgen therapy, tend to develop a more aggressive type which mainly consists of neuroendocrine cell clusters [48]. In malignant cell lines, NTSR1 expression was found in poorly differentiated (androgen receptor-negative) cell lines, whilst NTSR2 was found only in well-differentiated malignant cell lines. NTSR3 was found in all cell lines [40]. NTSR1 was also more highly expressed in basal-like phenotypes, which tend to lack AR, suggesting that NTSR1 supplies the mitogenic stimulus as an alternative pathway to carcinogenesis [40]. NTSR2 and NTSR3 were more highly expressed in luminal-like phenotypes [40]. Interestingly, in benign prostate tissue sections, NTSR1 was expressed in basal and luminal compartments, as well as in the stroma [40]. A more recent study, studying the NTSR1 expression in normal, benign prostatic hyperplasia $(\mathrm{BPH})$, prostatic cancer and metastatic lymph nodes, there was no clear association between NTSR1 and age, PSA values, Gleason score, pathological $\mathrm{T}$ stage, but there was more frequent NTSR1 overexpression in metastatic lymph nodes compared to 
primary tumours $(p=0.038)$ [49]. The authors concluded, in this study, that this may open a new perspective in imaging and radionuclide therapy in prostate cancer [49].

Deng and colleagues in 2017 used $3^{(64)} \mathrm{Cu}$ chelators which were conjugated to an NT analog and NTR binding affinity was evaluated using cell-binding assay, in human prostate cancer PC3 xenografts. PET/CT imaging of NTR expression showed high tumour uptake of the probes correlating with the in vitro Western blot results. The authors concluded that these agents may help identify NTR-positive lesions and predict which patients and individual tumours are likely to respond to novel interventions targeting NTSR1 [50].

Geer S and colleagues tested the uptake of Lu-177labelled NTSR1 antagonists into a cumulative tumour dose of $1.25 \mathrm{~Gy} / \mathrm{MBq}$, in prostate specific membrane antigen (PSMA) negative and NTSR1 positive prostate tumour-bearing nude mice. The tumour growth over 57 days and survival was significantly different between the treatment and control group, showing that NTSR1 could be a suitable molecular target in PSMA-negative prostate carcinoma for radiotherapy [51].

\section{Head and neck tumours}

Head and neck squamous cell carcinomas (HNSCC) represent $6 \%$ of all cancers and their overall 5-year survival is amongst the worst compared to other major cancer types [52]. This is largely due to local recurrence and distant metastasis after standard treatment, as well as the heterogeneity of the disease [53].

A study by Shimizu and colleagues in 2008 was the first to identify a link between NT-NTSR1 complex and HNSCC [52]. After a genome-wide gene expression analysis on HNSCC specimens revealed that high mRNA expression levels of NT and NTSR1 had a worse metastasis-free survival rate [52]. In HNSCC cells, the addition of NT promoted invasion and migration, whilst knockdown of the NTSR1 had the opposite effect [52].

\section{Pleural mesothelioma}

Malignant pleural mesothelioma (MPM) has a poor prognosis with a median survival of 8.9 months [54]. More recently, treatment with induction therapy and radical surgery has improved survival to greater than 20 months [55]. Unfortunately, only a small proportion of patients with MPM are eligible for such aggressive treatment due to late presentation, significant comorbidities and histological type [54].

In-vitro studies show that inhibition of the NT system reduced migration and collagen invasion of mesothelioma cells [54].

Thirty per cent and 77\% of normal pleura express NT and NTSR1 respectively [8]. In MPM, this percentage rises to 71.1 and $90.4 \%$ for NT and NTSR1, respectively. Interestingly, NTSR1 is expressed in the cytoplasm of tumoral cells, whilst it is expressed only on the cell membrane of normal pleural cells. High NT expression is associated with poor prognosis [54].

\section{Glioma}

Gliomas comprise $80 \%$ of all malignant brain tumours and despite the improvement in neurosurgery, radiotherapy and chemotherapy, their high recurrence rate accounts for the high mortality for these patients [56]. Gliomas are characterized by their rapid proliferation and extensive invasion, hence finding therapies to target this, would be of great interest [56].

NT is known to be present in the central nervous system and is highly expressed in the hypothalamus, median eminence, pituitary stalk, substantia nigra, locus coeruleus, raphe nuclei and brainstem structures [57]. In-vitro studies showed that NT stimulates Erk1/2 phosphorylation and is upregulated in glioma cells [58]. Both NT and NTSR1 is correlated with increasing glioma tumour grade [56]. In-vivo experiments in xenografted mice models showed that NTSR1 blockade significantly prolonged survival $[56,58]$.

Glioblastoma is the most aggressive brain tumour with a median overall survival of 12 to 15 months [59]. Among the gliomas, glioblastoma mutliforme (GBM) has the highest expression of NT and NTSR1 which in turn is associated with increased postoperative mortality [56]. Interestingly, different GBM cell lines express different receptors (GL261, U087MG, U-118MG and A172 lines express NTSR1; C6 line expresses NTSR2; U373MG line express NTSR1-3) [60].

The exact mechanism of NT in GBM is not well understood. Several in-vitro studies suggest that NT acts on glioblastoma stem cells (GSC) via an IL-8/CXCL8 mechanism [61]. NT activates NTSR1 and EGFR which in turn increased the expression of IL-8 and CXCL8 in GSC, which go on to activate the CXCR1 receptor. The latter activates the STAT3 transcriptional factor. This leads to increased proliferation, migration and invasion [62].

NT also seems to have an important role in protecting glioblastoma from intrinsic apoptosis via c-Myc/LIN28/ Let-7a-3p/Bcl-w axis [63]. NT increases tumour sphere formation and regulates stem-like traits via an EGFRdependent increase of interleukin-8 (IL-8) secretion [61].

NTSR1 activation increases CDK4 and CDK6 expression via $\mathrm{c}$-myc and $\mathrm{miR}-129-3 \mathrm{p} / \mathrm{miR} / 29 \mathrm{~b}-1$ respectively [64]. Furthermore, knockdown of NTSR1 reduces tumour invasion via the Jun/miR-494/SOCS6 axis [65].

\section{Liver cancer}

Hepatocellular carcinoma is a primary liver malignancy and the fourth commonest cause of cancer-related death 


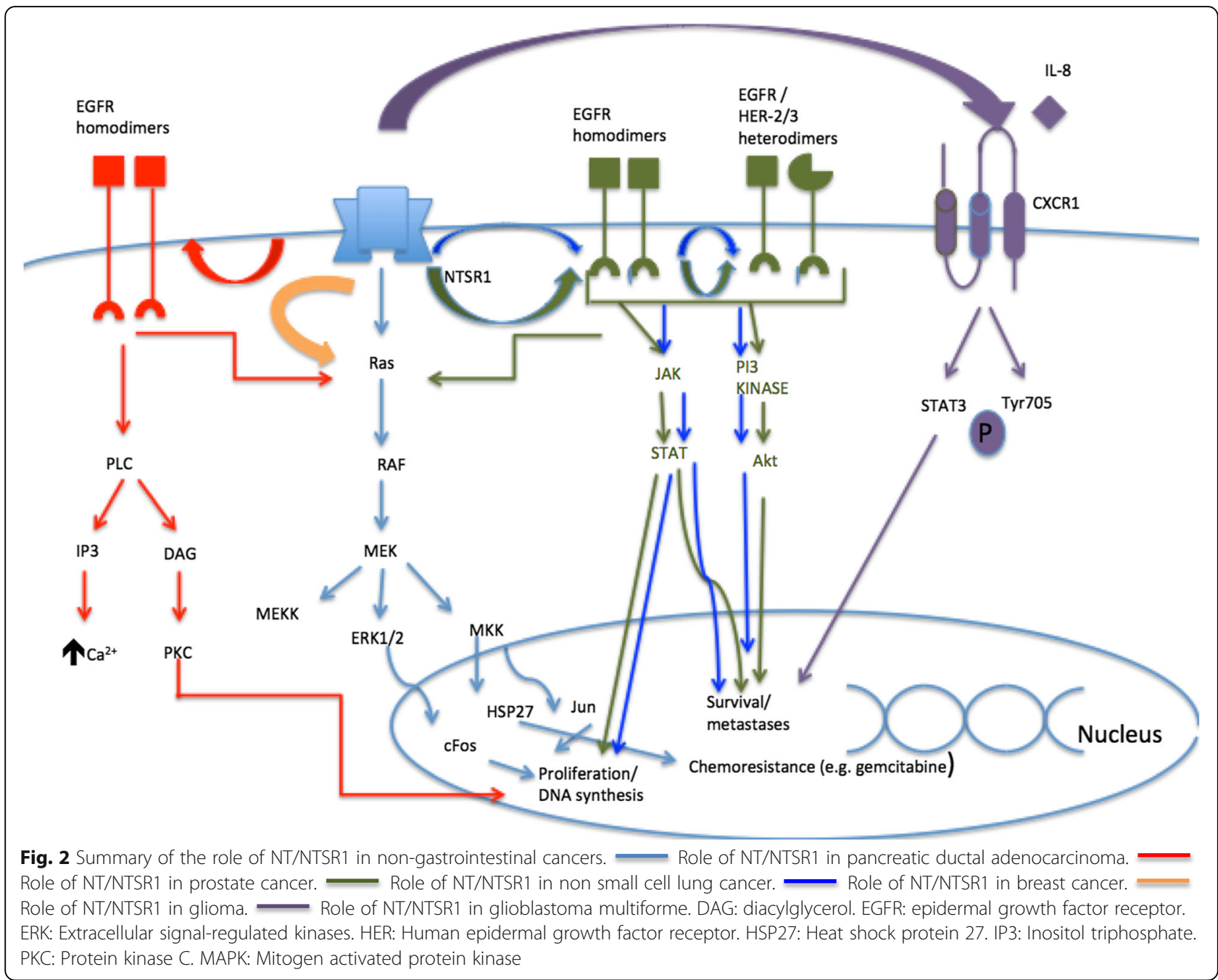

worldwide [66]. Underlying risk factors include chronic liver conditions, for example, chronic hepatitis B and C, alcohol addiction and non-alcoholic fatty liver disease [66]. Chronic inflammation is thought to be a driving factor for tumour invasion and progression, regardless of the cause $[67,68]$. NT has been reported to promote cytokine release, particularly IL-8 via the MAPK and NF-kB pathways, enhancing the migration and invasion capacity of HCC cells [69]. Overexpression of both interleukin-8 and NT in HCC has been associated with portal vein invasion and worse prognosis [69, 70]. Furthermore, co-expression of NT and NTSR1, found in $50 \%$ of HCC, has also been found to be correlated with poor prognosis and alteration of the $\mathrm{Wnt} / \mathrm{B}$-catenin pathway [71, 72].

Fibrolamellar hepatocellular carcinoma (FL-HCCs) is a rare form of HCC which tends to happen in teenagers and young adults, without underlying liver disease [73]. The underlying pathogenesis is due to an overexpression of the fusion protein DNAJ-PKAc and the PKAc kinase activity which depends on cyclic AMP (cAMP). NT and its receptors, NSTR1 and NTSR2, are a potential source of cAMP which in turn increases PKA activity [73]. In-vitro studies of cultured hepatocytes show that NT and NTSR1 act as co-mitogens on EGF signaling by promoting EGFR phosphorylation and MAPK pathway activation [73]. NT may also act in a paracrine/autocrine method, where NT binding to its GPCR, activates $N T$ gene expression, propagating NT protein production [73].

\section{Malignant melanoma}

Malignant Melanoma (MM) is a highly aggressive skin cancer with an increasing incidence worldwide [74]. Early detection and surgical excision can cure the disease, however more advanced stages are resistant to the current chemo-radiotherapy regimens, leading to a poor prognosis [75].

There has only been one study investigating the link between NT and MM. This showed that NT is highly expressed in melanoma cells(A375 and MV3 cells) but 
Table 1 A summary of Neurotensin (NT) and its receptors research studies

\begin{tabular}{|c|c|c|c|c|}
\hline Site of cancer & In-vitro & Animal models & Prognostic/Predictive studies & Clinical trials \\
\hline \multirow[t]{4}{*}{ Lung (NSCLC) } & \multirow{4}{*}{$\begin{array}{l}\text { Treatment with NT increased } \\
\text { growth in LMN-R cells }\end{array}$} & \multirow{4}{*}{$\begin{array}{l}\text { NTSR1 blockade potentiates effect of } \\
\text { geftinib }\end{array}$} & NTSR3 good prognostic marker & \multirow{6}{*}{$\begin{array}{l}\text { Afatinib in stage } \\
\text { IV bronchial } \\
\text { adenocarcinoma }\end{array}$} \\
\hline & & & $\begin{array}{l}\text { NTSR1 in cytoplasm a.w. poor } \\
\text { prognosis }\end{array}$ & \\
\hline & & & $\begin{array}{l}\text { NTSR1 predicts worse sensitivity to } \\
\text { platinum based treatments }\end{array}$ & \\
\hline & & & $\begin{array}{l}\text { NTSR2 expression has no correlation } \\
\text { to OS }\end{array}$ & \\
\hline \multirow[t]{2}{*}{$\begin{array}{l}\text { Pleural } \\
\text { mesothelioma }\end{array}$} & \multirow[t]{2}{*}{$\begin{array}{l}\text { NTSR1 antagonist reduced cell } \\
\text { invasion in MSTO- } 211 \mathrm{H} \text { cells }\end{array}$} & & $\begin{array}{l}\text { High NT expression is an independent } \\
\text { predictor of poor } 5 \text {-year survival }\end{array}$ & \\
\hline & & & NTSR1 had no impact of survival & \\
\hline \multirow[t]{2}{*}{ Pancreas } & $\begin{array}{l}\text { NTSR1 promotes DNA } \\
\text { synthesis, proliferation, } \\
\text { angiogenesis }\end{array}$ & & \multirow[t]{2}{*}{ NTSR1 increases with stage of disease } & \multirow[t]{2}{*}{$\mathrm{NI}$} \\
\hline & $\begin{array}{l}\text { NTSR3 increases migration in } \\
\text { individually migrating PDAC } \\
\text { cells }\end{array}$ & & & \\
\hline \multirow[t]{3}{*}{ Breast } & & $\begin{array}{l}\text { NTSR1 antagonist arrested tumour } \\
\text { growth in xenografted MDA-MB-231 } \\
\text { cells }\end{array}$ & \multirow{2}{*}{$\begin{array}{l}\text { High NTSR1 in patients with IDCs } \\
\text { correlated to higher histoprognostic } \\
\text { grade, larger tumour size and higher } \\
\text { number of positive lymph nodes }\end{array}$} & \multirow[t]{6}{*}{$\mathrm{NI}$} \\
\hline & & \multirow{2}{*}{$\begin{array}{l}\text { Suicide HSVtk gene delivery by NT- } \\
\text { polyplex nanoparticles + ganciclovir to } \\
\text { treat MDA-MB-231 cells }\end{array}$} & & \\
\hline & & & $\begin{array}{l}\text { High NTSR } 1 \text { expression is associated } \\
\text { with worse survival }\end{array}$ & \\
\hline \multirow[t]{3}{*}{ Prostate } & $\begin{array}{l}\text { NT/NTSR1 in PC3 cells } \\
\text { stimulates EGFR/ERK/Akt } \\
\text { phosphorylation and DNA } \\
\text { synthesis which is PKC- } \\
\text { dependent }\end{array}$ & \multirow{3}{*}{$\begin{array}{l}{ }^{(64)} \mathrm{Cu} \text { chelators conjugated to a NT } \\
\text { analog was assessed as an imaging } \\
\text { marker using PET/CT to was correlated } \\
\text { to NTSR1-positive lesions } \\
\text { Use of Lu-177-labelled NTSR1 antago- } \\
\text { nists in PSMA negative and NTSR1 posi- } \\
\text { tive prostate cancer nude mice showed } \\
\text { reduced tumour growth over } 57 \text { days }\end{array}$} & \multirow[t]{3}{*}{$\begin{array}{l}\text { There is more frequent NTSR1 } \\
\text { overexpression in metastatic lymph } \\
\text { nodes compared to primary tumours }\end{array}$} & \\
\hline & $\begin{array}{l}\text { NTSR1 is found in poorly } \\
\text { differentiated (androgen } \\
\text { receptor negative) } \\
\text { NTSR2 was found in well- } \\
\text { differentiated cell lines }\end{array}$ & & & \\
\hline & NTSR3 found in all cell lines & & & \\
\hline HNSCC & $\begin{array}{l}\text { Addition of NT promoted } \\
\text { invasion and migration. } \\
\text { Knockdown of NTSR1 slowed } \\
\text { invasion and migration }\end{array}$ & $\mathrm{NI}$ & $\begin{array}{l}\text { High mRNA expression of NT and } \\
\text { NTSR1 has a worse metastasis-free sur- } \\
\text { vival rate }\end{array}$ & $\mathrm{NI}$ \\
\hline \multirow{3}{*}{$\begin{array}{l}\text { Glioma } \\
\text { Glioblastoma } \\
\text { multiforme } \\
\text { (GBM) }\end{array}$} & $\begin{array}{l}\text { NT stimulates ERK1/2 } \\
\text { phosphorylation }\end{array}$ & $\begin{array}{l}\text { NTSR1 blockade in xenografted nude } \\
\text { mice increased survival }\end{array}$ & $\mathrm{NI}$ & $\mathrm{NI}$ \\
\hline & $\begin{array}{l}\text { Different GBM cell lines express } \\
\text { different NT receptors }\end{array}$ & \multirow[t]{2}{*}{$\mathrm{NI}$} & \multirow[t]{2}{*}{$\mathrm{NI}$} & \multirow[t]{2}{*}{$\mathrm{NI}$} \\
\hline & $\begin{array}{l}\text { Studies on glioblastoma stem } \\
\text { cells show that NT acts } \\
\text { through the CXCR1/2/IL-8 } \\
\text { pathway which is EGFR- } \\
\text { dependent }\end{array}$ & & & \\
\hline
\end{tabular}

CXCR CXC chemokine receptor, EGFR epidermal growth factor receptor, ERK extracellular signal-regulated kinase, IDC invasive ductal carcinoma (breast), IL-8 interleukin 8, MDA-MB-231 triple negative breast cancer cells, NTSR neurotensin receptor, NI not investigated, OS overall survival, PC3 cell line from bone metastasis of prostate cancer patient, PDAC pancreatic ductal adenocarcinoma cells, PKC protein kinase C, PSMA prostate specific antigen

its expression in normal immortalized human keratinocyte line $\mathrm{HaCaT}$ is low [75]. The same study found that NT/NTSR1 activation is required for cell migration in the A375 melanoma cells. Inhibition of NTSR1 with SR48692 antagonist induced apoptosis in A375 melanoma cell line and reduced tumour growth in vivo [75]. The authors suggested that NTSR1 may be a novel drug target in melanoma, however, there are no further studies to investigate its potential.

\section{Leukaemias}

In-vitro studies show that NTSR1 is expressed in HL-60 human myeloid leukaemia cells [76]. 
NT, NTSR1, NTSR2 and NTSR3 are all expressed in human B cell lines [77]. Exogenous NT promotes proliferation and apoptosis in human B cell lines via the NSTR1 activation pathway [77]. NTSR2 and NTSR3 were also overexpressed in chronic lymphocytic leukaemia (CLL) B cells [77, 78]. Farahi and colleagues postulated that NSTR3 expression could potentially be a diagnostic but not a prognostic marker in CLL [78]. He further showed that treatment with monoclonal antibodies against NSTR3 selectively killed CLL cells but not healthy peripheral blood mononuclear cells (PBMCs) [78].

\section{Miscellaneous}

NT receptors have been found in varying degrees in Ewing's sarcoma, meningiomas, sarcomas, astrocytomas, medulloblastomas and medullary thyroid carcinomas [79].

\section{Conclusion}

Preliminary studies have shown NT and its receptors to promote cell proliferation, DNA synthesis, migration and angiogenesis through autocrine and paracrine effects in many cancers (Fig. 2). Their direct effect on MAPK pathway, EGFR transactivation and Protein kinase $\mathrm{C}$ and $\mathrm{D}$ pathway activation makes them an interesting target in therapeutic use in the subset of cancers which express NT and/or its receptors, making way for a promising new tumour agnostic drug. They also show potential as prognostic and predictive markers. Although there is promise in the use of these markers in animal models, further study is required to assess its applicability in clinical use (Table 1).

\footnotetext{
Abbreviations

AR: Androgen receptor; BPH: Benign prostatic hyperplasia; CDK: Cyclindependent kinase; CLL: Chronic lymphocytic leukaemia; CpG: Cytosinephosphorus-guanine; Cu: Copper; CXCL8: Chemokine (C-X-C) ligand; CXCR: Chemokine receptor; DAG: Diacylglycerol; DNA: Deoxyribonucleic acid; EGFR: Epidermal growth factor; EMT: Epithelial-to-mesenchymal transition; ERK: Extracellular signal-regulated kinases; GBM: Glioblastoma multiforme; GSC: Glioblastoma stem cells; IL-8: Interleukin-8; IDC: Invasive ductal carcinoma; FAK: Focal Adhesion kinase; HER: Human epidermal growth factor receptor; HNSCC: Head and neck squamous cell carcinomas; IP3: Inositol 1,4,5- triphosphate; MAPK: Mitogen-activated protein kinase; MDA-MB-231: Is a highly aggressive triple negative breast cancer cell line; MMP: Matric metalloproteinases; MPM: Malignant pleural mesothelioma; OS: Overall survival; PKC: Protein Kinase C; PLC: Phospholipase C; LF-NT: Long fragment NT; RAP: Receptor-associated protein; NHE1: Sodium/ Hydrogen exchanger 1; NSCLC: Non-small cell lung carcinoma; NT: Neurotensin; NTSR1: Neurotensin receptor 1; NTSR2: Neurotensin receptor 2; NTSR3: Neurotensin receptor 3; PANC: Pancreatic cancer cell line; PC3: Prostate cancer cell line; PDAC: Pancreatic ductal adenocarcinoma; PSA: Prostate specific antigen; PSMA: Prostate specific membrane antigen; SAP: Sphingolipid activator protein; SBR: Scarff-Bloom-Richardson grading score; SCLC: Small cell lung carcinoma; sNTSR: Soluble Neurotensin receptor; THEN: The Neurotensinneurotensin receptor complex
}

\section{Authors' contributions}

All authors read and approved the final manuscript.

\section{Funding}

The authors did not receive funding for this work.
Availability of data and materials

Not applicable.

\section{Consent for publication}

Not applicable.

\section{Competing interests}

The authors declare they have no conflict of interest.

\section{Author details}

'Department of Colorectal Surgery, Chelsea and Westminster Hospital, NHS Foundation Trust, London, UK. ²Department of Colorectal Surgery, Royal Marsden Hospital, London, UK. ${ }^{3}$ Department of Surgery and Cancer, Imperial College London, Chelsea and Westminster Campus, 369 Fulham Road, London SW10 9NH, UK.

Received: 6 December 2019 Accepted: 27 March 2020

Published online: 26 April 2020

\section{References}

1. Theodorsson-Norheim E, Oberg K, Rosell S, Bostrom H. Neurotensinlike immunoreactivity in plasma and tumor tissue from patients with endocrine tumors of the pancreas and gut. Gastroenterology. 1983;85(4):881-9.

2. Evers BM. Neurotensin and growth of normal and neoplastic tissues. Peptides. 2006:27(10):2424-33.

3. Kitabgi P. Targeting neurotensin receptors with agonists and antagonists for therapeutic purposes. Curr Opin Drug Discov Devel. 2002;5(5):764-76.

4. Thor K, Rosell S. Neurotensin increases colonic motility. Gastroenterology. 1986:90(1):27-31.

5. Gullo $L$. The effect of neurotensin on pure pancreatic secretion in man. Scand J Gastroenterol. 1987;22(3):343-8.

6. Ouyang Q, Zhou J, Yang W, Cui H, Xu M, Yi L. Oncogenic role of neurotensin and neurotensin receptors in various cancers. Clin Exp Pharmacol Physiol. 2017:44(8):841-6.

7. Evers BM. Endocrine gene neurotensin: molecular mechanisms and a model of intestinal differentiation. World J Surg. 2002;26(7):799-805.

8. Wu Z, Martinez-Fong D, Tredaniel J, Forgez P. Neurotensin and its high affinity receptor 1 as a potential pharmacological target in cancer therapy. Front Endocrinol. 2012;3:184.

9. Wilson CM, Naves T, Vincent F, Melloni B, Bonnaud F, Lalloue F, et al. Sortilin mediates the release and transfer of exosomes in concert with two tyrosine kinase receptors. J Cell Sci. 2014;127(Pt 18):3983-97.

10. Qiu S, Pellino G, Fiorentino F, Rasheed S, Darzi A, Tekkis P, et al. A review of the role of Neurotensin and its receptors in colorectal Cancer. Gastroenterol Res Pract. 2017;2017:6456257.

11. Alifano M, Souaze F, Dupouy S, Camilleri-Broet S, Younes M, Ahmed-Zaid SM, et al. Neurotensin receptor 1 determines the outcome of non-small cell lung cancer. Clin Cancer Res. 2010;16(17):4401-10.

12. Younes M, Wu Z, Dupouy S, Lupo AM, Mourra N, Takahashi T, et al. Neurotensin (NTS) and its receptor (NTSR1) causes EGFR, HER2 and HER3 over-expression and their autocrine/paracrine activation in lung tumors, confirming responsiveness to erlotinib. Oncotarget. 2014;5(18):8252-69.

13. Liang $H$, Liu X, Wang M. Immunotherapy combined with epidermal growth factor receptor-tyrosine kinase inhibitors in non-small-cell lung cancer treatment. Onco Targets Ther. 2018;11:6189-96.

14. Davis TP, Crowell S, McInturff B, Louis R, Gillespie T. Neurotensin may function as a regulatory peptide in small cell lung cancer. Peptides. 1991; 12(1):17-23.

15. Wakabayashi-Nakao K, Maruyama K, Ishii H, Muramatsu K, Hatakeyama K, Ohshima K, et al. Investigation of proNT/NMN secretion from small cell lung carcinoma cells using a mouse xenograft model. Oncol Rep. 2012;28(4): 1181-6.

16. Moody TW, Chan DC, Mantey SA, Moreno P, Jensen RT. SR48692 inhibits non-small cell lung cancer proliferation in an EGF receptor-dependent manner. Life Sci. 2014:100(1):25-34.

17. Moody TW, Moreno P, Jensen RT. Neuropeptides as lung cancer growth factors. Peptides. 2015;72:106-11.

18. Wu Z, Fournel L, Stadler N, Liu J, Boullier A, Hoyeau N, et al. Modulation of lung cancer cell plasticity and heterogeneity with the restoration of cisplatin sensitivity by neurotensin antibody. Cancer Lett. 2019;444:147-61. 
19. Al-Akhrass H, Naves T, Vincent F, Magnaudeix A, Durand K, Bertin F, et al. Sortilin limits EGFR signaling by promoting its internalization in lung cancer. Nat Commun. 2017;8(1):1182.

20. Wang L, Friess $\mathrm{H}$, Zhu Z, Graber H, Zimmermann A, Korc M, et al. Neurotensin receptor-1 mRNA analysis in normal pancreas and pancreatic disease. Clin Cancer Res. 2000;6(2):566-71 2000(1078-0432 (Print)):566-71.

21. Ishizuka J, Townsend CM, Thompson JC. Neurotensin regulates growth of human pancreatic cancer. 1993;217(5):439-45.

22. Ryder NM, Guha S, Hines OJ, Reber HA, Rozengurt E. G protein-coupled receptor signaling in human ductal pancreatic cancer cells: neurotensin responsiveness and mitogenic stimulation. J Cell Physiol. 2001;186(1):53-64.

23. Guha S, Rey O, Rozengurt E. Neurotensin induces protein kinase Cdependent protein kinase D activation and DNA synthesis in human pancreatic carcinoma cell line PANC-1. Cancer Res. 2002;62(6):1632-40.

24. Kisfalvi K, Guha S, Rozengurt E. Neurotensin and EGF induce synergistic stimulation of DNA synthesis by increasing the duration of ERK signaling in ductal pancreatic cancer cells. J Cell Physiol. 2005;202(3):880-90.

25. Ehlers RA, Zhang Y, Hellmich MR, Evers BM. Neurotensin-mediated activation of MAPK pathways and AP-1 binding in the human pancreatic cancer cell line, MIA PaCa-2. Biochem Biophys Res Commun. 2000;269(3): 704-8.

26. Olszewski U, Hlozek M, Hamilton G. Activation of $\mathrm{Na}+/ \mathrm{H}+$ exchanger 1 by neurotensin signaling in pancreatic cancer cell lines. Biochem Biophys Res Commun. 2010;393(3):414-9.

27. Mijatovic T, Gailly P, Mathieu V, De Neve N, Yeaton P, Kiss R, et al. Neurotensin is a versatile modulator of in vitro human pancreatic ducta adenocarcinoma cell (PDAC) migration. Cell Oncol. 2007;29(4):315-26.

28. Wang JG, Li NN, Li HN, Cui L, Wang P. Pancreatic cancer bears overexpression of neurotensin and neurotensin receptor subtype-1 and SR 48692 counteracts neurotensin induced cell proliferation in human pancreatic ductal carcinoma cell line PANC-1. Neuropeptides. 2011;45(2):151-6.

29. Reubi JC, Waser B, Friess H, Buchler M, Laissue J. Neurotensin receptors: a new marker for human ductal pancreatic adenocarcinoma. Gut. 1998;42(4): 546-50

30. Baum RP, Singh A, Schuchardt C, Kulkarni HR, Klette I, Wiessalla S, et al. (177)Lu3BP-227 for Neurotensin receptor 1-targeted therapy of metastatic pancreatic adenocarcinoma: first clinical results. J Nucl Med. 2018;59(5):809-14.

31. Schulz J, Rohracker M, Stiebler M, Goldschmidt J, Grosser OS, Osterkamp F, et al. Comparative evaluation of the biodistribution profiles of a series of Nonpeptidic Neurotensin Receptor-1 antagonists reveals a promising candidate for Theranostic applications. J Nucl Med. 2016;57(7):1120-3.

32. Schulz J, Rohracker M, Stiebler M, Goldschmidt J, Stober F, Noriega M, et al. Proof of therapeutic efficacy of a (177)Lu-labeled Neurotensin receptor 1 antagonist in a Colon carcinoma Xenograft model. J Nucl Med. 2017;58(6): 936-41.

33. Trials c. Study to Evaluate the Safety and Activity (Including Distribution) of 177Lu-3BP-227 in Subjects With Solid Tumours Expressing Neurotensin Receptor Type 1. 2019 [Available from: https://clinicaltrials.gov/ct2/show/ NCT03525392?term=NTSR1\&rank=3.

34. Dupouy S, Viardot-Foucault V, Alifano M, Souaze F, Plu-Bureau G, Chaouat $M$, et al. The neurotensin receptor-1 pathway contributes to human ducta breast cancer progression. PLoS One. 2009;4(1):e4223.

35. Dupouy S, Mourra N, Doan VK, Gompel A, Alifano M, Forgez P. The potentia use of the neurotensin high affinity receptor 1 as a biomarker for cance progression and as a component of personalized medicine in selective cancers. Biochimie. 2011;93(9):1369-78.

36. Melander $O$, Maisel AS, Almgren $P$, Manjer J, Belting $M$, Hedblad B, et al. Plasma proneurotensin and incidence of diabetes, cardiovascular disease, breast cancer, and mortality. JAMA. 2012;308(14):1469-75.

37. Dupouy S, Doan VK, Wu Z, Mourra N, Liu J, De Wever O, et al. Activation of EGFR, HER2 and HER3 by neurotensin/neurotensin receptor 1 renders breast tumors aggressive yet highly responsive to lapatinib and metformin in mice. Oncotarget. 2014;5(18):8235-51.

38. Souaze F, Dupouy S, Viardot-Foucault V, Bruyneel E, Attoub S, Gespach C, et al. Expression of neurotensin and NT1 receptor in human breast cancer: a potential role in tumor progression. Cancer Res. 2006;66(12):6243-9.

39. Castillo-Rodriguez RA, Arango-Rodriguez ML, Escobedo L, HernandezBaltazar D, Gompel A, Forgez P, et al. Suicide HSVtk gene delivery by neurotensin-polyplex nanoparticles via the bloodstream and GCV treatment specifically inhibit the growth of human MDA-MB-231 triple negative breast cancer tumors xenografted in athymic mice. PLoS One. 2014;9(5):e97151.
40. Swift SL, Burns JE, Maitland NJ. Altered expression of neurotensin receptors is associated with the differentiation state of prostate cancer. Cancer Res. 2010;70(1):347-56

41. Vias M, Burtt G, Culig Z, Veerakumarasivam A, Neal DE, Mills IG. A role for neurotensin in bicalutamide resistant prostate cancer cells. Prostate. 2007; 67(2):190-202.

42. Sehgal I, Powers S, Huntley B, Powis G, Pittelkow M, Maihle NJ. Neurotensin is an autocrine trophic factor stimulated by androgen withdrawal in human prostate cancer. Proc Natl Acad Sci U S A. 1994;91(11):4673-7.

43. Amorino GP, Deeble PD, Parsons SJ. Neurotensin stimulates mitogenesis of prostate cancer cells through a novel c-Src/Stat5b pathway. Oncogene. 2007;26(5):745-56

44. DaSilva JO, Amorino GP, Casarez EV, Pemberton B, Parsons SJ. Neuroendocrine-derived peptides promote prostate cancer cell survival through activation of IGF-1R signaling. Prostate. 2013;73(8):801-12.

45. Hassan S, Dobner PR, Carraway RE. Involvement of MAP-kinase, PI3-kinase and EGF-receptor in the stimulatory effect of Neurotensin on DNA synthesis in PC3 cells. Regul Pept. 2004;120(1-3):155-66.

46. Zhu S, Tian H, Niu X, Wang J, Li X, Jiang N, et al. Neurotensin and its receptors mediate neuroendocrine transdifferentiation in prostate cancer. Oncogene. 2019:38(24):4875-4884.

47. Valerie NC, Casarez EV, Dasilva JO, Dunlap-Brown ME, Parsons SJ, Amorino $\mathrm{GP}$, et al. Inhibition of neurotensin receptor 1 selectively sensitizes prostate cancer to ionizing radiation. Cancer Res. 2011;71(21):6817-26.

48. Oesterling JE, Hauzeur CG, Farrow GM. Small cell anaplastic carcinoma of the prostate: a clinical, pathological and immunohistological study of 27 patients. J Urol. 1992;147(3 Pt 2):804-7.

49. Morgat C, Chastel A, Molinie V, Schollhammer R, Macgrogan G, Velasco V, et al. Neurotensin Receptor-1 Expression in Human Prostate Cancer: A Pilot Study on Primary Tumors and Lymph Node Metastases. Int J Mole Sci. 2019;20(7).

50. Deng $H$, Wang $H$, Zhang $H$, Wang $M$, Giglio B, Ma X, et al. Imaging Neurotensin receptor in prostate Cancer with (64)cu-labeled Neurotensin analogs. Mol Imaging. 2017;16:1536012117711369.

51. S G, U R, S M, P R, O P, P G, et al. The neurotensin receptor subtype 1 as target for radiotherapy in prostate cancer, vol. 60; 2017

52. Shimizu S, Tsukada J, Sugimoto T, Kikkawa N, Sasaki K, Chazono H, et al. Identification of a novel therapeutic target for head and neck squamous cell carcinomas: a role for the neurotensin-neurotensin receptor 1 oncogenic signaling pathway. Int J Cancer. 2008;123(8):1816-23.

53. Rothenberg SM, Ellisen LW. The molecular pathogenesis of head and neck squamous cell carcinoma. J Clin Invest. 2012;122(6):1951-7.

54. Alifano M, Loi M, Camilleri-Broet S, Dupouy S, Regnard JF, Forgez P. Neurotensin expression and outcome of malignant pleural mesothelioma. Biochimie. 2010:92(2):164-70.

55. Weder W, Stahel RA, Bernhard J, Bodis S, Vogt P, Ballabeni P, et al. Multicenter trial of neo-adjuvant chemotherapy followed by extrapleural pneumonectomy in malignant pleural mesothelioma. Ann Oncol. 2007; 18(7):1196-202.

56. Ouyang Q, Gong X, Xiao H, Zhou J, Xu M, Dai Y, et al. Neurotensin promotes the progression of malignant glioma through NTSR1 and impacts the prognosis of glioma patients. Mol Cancer. 2015;14:21.

57. Polak JM, Bloom SR. The central and peripheral distribution of neurotensin. Ann N Y Acad Sci. 1982:400:75-93.

58. Yi L, Xiao H, Xu M, Ye X, Hu J, Li F, et al. Glioma-initiating cells: a predominant role in microglia/macrophages tropism to glioma. J Neuroimmunol. 2011;232(1-2):75-82.

59. Meyer MA. Malignant gliomas in adults. N Engl J Med. 2008;359(17):1850 author reply.

60. Korbecki J, Gutowska I, Kojder I, Jezewski D, Goschorska M, Lukomska A, et al. New extracellular factors in glioblastoma multiforme development: neurotensin, growth differentiation factor-15, sphingosine-1-phosphate and cytomegalovirus infection. Oncotarget. 2018;9(6):7219-70.

61. Zhou J, Yi L, Ouyang Q, Xu L, Cui H, Xu M. Neurotensin signaling regulates stem-like traits of glioblastoma stem cells through activation of IL-8/CXCR1/ STAT3 pathway. Cell Signal. 2014;26(12):2896-902.

62. Infanger DW, Cho Y, Lopez BS, Mohanan S, Liu SC, Gursel D, et al. Glioblastoma stem cells are regulated by interleukin-8 signaling in a tumoral perivascular niche. Cancer Res. 2013;73(23):7079-89.

63. Dong Z, Lei Q, Yang R, Zhu S, Ke XX, Yang L, et al. Inhibition of neurotensin receptor 1 induces intrinsic apoptosis via let-7a-3p/Bcl-w axis in glioblastoma. Br J Cancer. 2017;116(12):1572-84. 
64. Ouyang Q, Chen G, Zhou J, Li L, Dong Z, Yang R, et al. Neurotensin signaling stimulates glioblastoma cell proliferation by upregulating c-Myc and inhibiting miR-29b-1 and miR-129-3p. Neuro-oncology. 2016;18(2):216-26.

65. Ou-Yang Q, He X, Yang A, Li B, Xu M. Interference with NTSR1 expression exerts an anti-invasion effect via the Jun/miR-494/SOCS6 Axis of Glioblastoma cells. Cell Physiol Biochem. 2018;49(6):2382-95.

66. Yang JD, Hainaut P, Gores GJ, Amadou A, Plymoth A, Roberts LR. A global view of hepatocellular carcinoma: trends, risk, prevention and management. Nat Rev Gastroenterol Hepatol. 2019;16(10):589-604.

67. Chen $S$, Dong $Z$, Yang $P$, Wang $X$, Jin $G$, Yu $H$, et al. Hepatitis $B$ virus $X$ protein stimulates high mobility group box 1 secretion and enhances hepatocellular carcinoma metastasis. Cancer Lett. 2017;394:22-32.

68. Cheng S, Zhang B, Du JY, Jin YH, Lang HY, Zeng LH. Hepatitis B surface antigen promotes the invasion of hepatitis $B$ virus-related hepatocellular carcinoma cells by Upregulation of toll-like receptor 2. Viral Immunol. 2017; 30(3):232-9.

69. Xiao P, Long X, Zhang L, Ye Y, Guo J, Liu P, et al. Neurotensin/L-8 pathway orchestrates local inflammatory response and tumor invasion by inducing M2 polarization of tumor-associated macrophages and epithelialmesenchymal transition of hepatocellular carcinoma cells. Oncoimmunology. 2018;7(7):e1440166.

70. Yu J, Ren X, Chen Y, Liu P, Wei X, Li H, et al. Dysfunctional activation of neurotensin/LL-8 pathway in hepatocellular carcinoma is associated with increased inflammatory response in microenvironment, more epithelial mesenchymal transition in cancer and worse prognosis in patients. PLoS One. 2013;8(2):e56069.

71. Ye Y, Long X, Zhang L, Chen J, Liu P, Li H, et al. NTS/NTR1 co-expression enhances epithelial-to-mesenchymal transition and promotes tumor metastasis by activating the Wnt/beta-catenin signaling pathway in hepatocellular carcinoma. Oncotarget. 2016;7(43):70303-22.

72. Wu Z, Galmiche A, Liu J, Stadler N, Wendum D, Segal-Bendirdjian E, et al. Neurotensin regulation induces overexpression and activation of EGFR in HCC and restores response to erlotinib and sorafenib. Cancer Lett. 2017:388:73-84.

73. Riehle KJ, Kenerson HL, Riggle KM, Turnham R, Sullivan K, Bauer R, et al. Neurotensin as a source of cyclic AMP and co-mitogen in fibrolamellar hepatocellular carcinoma. Oncotarget. 2019;10(49):5092-102.

74. Nakamura Y, Fujisawa Y. Diagnosis and Management of Acral Lentiginous Melanoma. Curr Treat Options in Oncol. 2018;19(8):42.

75. Zhang Y, Zhu S, Yi L, Liu Y, Cui H. Neurotensin receptor1 antagonist SR48692 reduces proliferation by inducing apoptosis and cell cycle arrest in melanoma cells. Mol Cell Biochem. 2014;389(1-2):1-8.

76. Choi SY, Chae HD, Park TJ, Ha H, Kim KT. Characterization of high affinity neurotensin receptor NTR1 in $\mathrm{HL}-60$ cells and its down regulation during granulocytic differentiation. Br J Pharmacol. 1999;126(4):1050-6.

77. Saada S, Marget P, Fauchais AL, Lise MC, Chemin G, Sindou P, et al. Differential expression of neurotensin and specific receptors, NTSR1 and NTSR2, in normal and malignant human B lymphocytes. J Immunol (Baltimore, Md : 1950). 2012:189(11):5293-303.

78. Farahi L, Ghaemimanesh F, Milani S, Razavi SM, Akhondi MM, Rabbani H. Sortilin as a novel diagnostic and therapeutic biomarker in chronic lymphocytic leukemia. Avicenna J Med Biotechnol. 2019;11(4):270-6.

79. Reubi JC, Waser B, Schaer JC, Laissue JA. Neurotensin receptors in human neoplasms: high incidence in Ewing's sarcomas. Int J Cancer. 1999;82(2):213-8.

\section{Publisher's Note}

Springer Nature remains neutral with regard to jurisdictional claims in published maps and institutional affiliations.

Ready to submit your research? Choose BMC and benefit from:
- fast, convenient online submission
- thorough peer review by experienced researchers in your field
- rapid publication on acceptance
- support for research data, including large and complex data types
- gold Open Access which fosters wider collaboration and increased citations
- maximum visibility for your research: over 100M website views per year
At BMC, research is always in progress.
Learn more biomedcentral.com/submissions

